\title{
A review of progress in understanding the pathophysiology and treatment of brain edema
}

\author{
Anthony Marmarou, Ph.D. \\ Department of Neurosurgery, Virginia Commonwealth University Medical Center, Richmond, Virginia
}

\begin{abstract}
Object. Brain edema resulting from traumatic brain injury (TBI) or ischemia if uncontrolled exhausts volume reserve and leads to raised intracranial pressure and brain herniation. The basic types of edema-vasogenic and cytotoxic-were classified 50 years ago, and their definitions remain intact.

Methods. In this paper the author provides a review of progress over the past several decades in understanding the pathophysiology of the edematous process and the success and failures of treatment. Recent progress focused on those manuscripts that were published within the past 5 years.

Results. Perhaps the most exciting new findings that speak to both the control of production and resolution of edema in both trauma and ischemia are the recent studies that have focused on the newly described "water channels" or aquaporins. Other important findings relate to the predominance of cellular edema in TBI.

Conclusions. Significant new findings have been made in understanding the pathophysiology of brain edema; however, less progress has been made in treatment. Aquaporin water channels offer hope for modulating and abating the devastating effects of fulminating brain edema in trauma and stroke.
\end{abstract}

KEY WORDS - brain edema • ischemic edema - traumatic edema - vasogenic edema

$\mathrm{T}$ HE CONTRIBUTION OF brain edema to brain swelling in cases of traumatic injury, ischemia, and tumor remains a critical problem for which there is currently no effective clinical treatment. It is also well documented that in head injury, swelling leads to elevations in ICP, which is a frequent cause of death, and to poor prognosis among survivors. ${ }^{44,100,112,151,152}$ A poor prognosis is certain when secondary insults of hypotension or hypoxia are added to the mechanical injury. ${ }^{31}$ In the case of TBI, the swelling process has been classified into four distinct degrees of severity based on studies in the Traumatic Coma Data Bank. ${ }^{106-108}$ Of great importance is the fact that the degree of swelling assessed on the first computed tomography scan, obtained soon after injury, was highly correlated with outcome $(\mathrm{p}<0.0002),{ }^{40}$ and it suggests that therapy must be commenced as soon as possible to avoid neurological deterioration or even death. The rise in ICP may be swift, and brain herniation and death can occur within 36 hours postinjury despite aggressive therapy of mannitol, vasopressors, hyperventilation, and barbiturates. The reason for this may be explained by the exponential relationship between ICP and brain water content.

Abbreviations used in this paper: $\mathrm{ADC}=$ apparent diffusion coefficient; $\mathrm{APQ}=$ aquaporin; $\mathrm{BBB}=$ blood-brain barrier; $\mathrm{CBF}=$ cerebral blood flow; $\mathrm{CSF}=$ cerebrospinal fluid; ICP = intracranial pressure; $\mathrm{MR}=$ magnetic resonance; $\mathrm{TBI}=$ traumatic brain injury.
As edema develops, a threshold is reached in which ICP rises exponentially to small changes in brain edema. ${ }^{105}$

This clearly emphasizes the need for a better understanding of the processes leading to brain swelling, and most important, the means by which these processes can be abated. In this manuscript I review the most recent concepts and advances in the pathobiology of brain edema and the implications for treatment.

\section{Types of Edema and Implications for Treatment}

By definition, edema is an abnormal accumulation of fluid within the brain parenchyma; it is subdivided into vasogenic and cytotoxic types. ${ }^{84}$ Other labels of edema such as osmotic, interstitial (hydrostatic), or hyperemic refer to etiology rather than physical location. ${ }^{176}$ Vasogenic edema is defined as fluid originating from blood vessels that accumulates around cells. Cytotoxic edema is defined as fluid accumulating within cells as a result of injury. The most common cytotoxic edema occurs in cerebral ischemia. Heretofore, the edema specific to TBI has generally been considered to be of vasogenic origin, secondary to traumatic opening of the BBB..$^{15-17}$ However, both forms of edema can coexist. This is a critical problem, as effective treatment will clearly depend on the major type of edema contributing to the swelling process.

In the case of vasogenic edema, protein extravasation 
secondary to barrier compromise was implicated in the edematous process..$^{91}$ This was in line with Klatzos' theory that a breakdown of the extracellular proteins would increase the osmotic gradient and cause more water to exude from the vessels. It was shown that protein in the extracellular space retards the clearance of fluid, ${ }^{52}$ but no evidence to date has been put forth to substantiate that extracellular protein increases fluid entry into brain. Just as protein in the extracellular space has been shown to retard clearance, lowering the ICP enhances clearance of fluid from the brain, while steroids have negligible effect on the clearance process. ${ }^{68}$ Mediator compounds such as bradykinin, glutamate, arachidonic acid, and leukotrienes are released upon brain injury and cause brain swelling. ${ }^{13}$, $14,36,47,59,61,80,81,96,125,146,150,161,164,167,174,175$ Pharmacological treatments in the laboratory setting have shown positive effects to varying degrees; $47,50,61,76,81,114,125,167$ however, these treatments have not been translated to the patient. Moreover, mannitol, which is in common use after stroke, has not been shown to be effective, despite a plethora of nonrandomized in-hospital trials. ${ }^{18}$

\section{The Importance of Cellular Edema}

The treatment of cellular edema is far more complex, given that a precise identification of the processes that govern resolution as well as entry of fluid into the cell is unknown. Cellular brain edema is a life-threatening complication of cerebral infarction. ${ }^{147}$ The molecular cascade initiated by cerebral ischemia includes the loss of membrane ionic pumps and cell swelling. Secondary formation of free radicals and proteases disrupts brain cell membranes, causing irreversible damage. New diagnostic methods based on MR imaging have markedly improved diagnostic accuracy. Cytotoxic and vasogenic edema aregreatest by 24 to 72 hours after the ischemic event. Thrombolytics reperfuse tissue and improve outcome; when treatment is delayed, they can increase edema and BBB opening. Although osmotherapy reduces brain water and is used to treat ischemic edema, its efficacy remains to be proven. With regard to trauma, the use of experimental models of head injury in earlier work has shown that drugs inhibiting $\mathrm{K}^{+}$-stimulated $\mathrm{HCO}_{3}$-dependent swelling of brain cerebrocortical slices were effective in inhibiting astrocytic swelling. Qualitative and quantitative electron microscope studies have shown that members of the fluorenyl class of drugs inhibit astrocytic swelling associated with an experimental animal head injury model. It was posited that astrocytic swelling in pathological states may be partly due to activation of $\mathrm{Cl} / \mathrm{HCO}_{3}{ }^{-}$and $\mathrm{Na}^{+} / \mathrm{H}^{+}$exchange systems driven by increased astrocytic intracellular hydration of $\mathrm{CO}_{2}$.

\section{Cellular Edema in Ischemia}

Results of both experimental and clinical studies have indicated that cerebral edema develops following acute regional ischemia and can cause mass effect and herniation that results in a further decrease in CBF. Complete interruption of $\mathrm{CBF}$, as induced in cardiac arrest, results in the rapid breakdown of all electrophysiological and metabolic functions of the brain. ${ }^{63}$ The edema associated with ischemia has a characteristic time course and begins with a cytotoxic phase in which energy failure results in intracellular fluid accumulation associated with shifts in sodium and potassium between intra- and extracellular com-

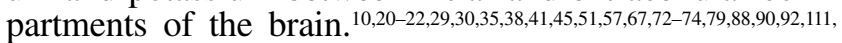
$126,131,142,145,148,154,155,179,191,195$ With ongoing ischemia, the core region of impaired metabolism expands, leading to gradual infarction of the penumbra. ${ }^{62}$ Treatments for the combination of ischemic edema and eventual vasogenic edema secondary to barrier compromise have not been successful, and more work needs to be done, not only to elucidate the pathophysiology but to better understand the

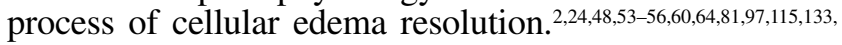
138-141,165,182,187,194

\section{Edema Development Following Intracerebral Hemorrhage}

The vasogenic and cellular components of edema following trauma and/or ischemia are well described. However, the cause of the edema development following intracerebral hemorrhage remains unknown. Studies involving stereotactic injection of various blood products such as concentrated blood cells, serum from clotted blood, and plasma from unclotted blood all failed to produce experimental edema in rodents. However, the introduction of prothrombinase to plasma to activate the coagulation cascade produced brain edema. ${ }^{99}$ Authors of subsequent studies have demonstrated that thrombin increased brain edema when concentrations as low as $1 \mathrm{U} / \mu \mathrm{l}$ were infused into rodent brain. ${ }^{98}$ Work is ongoing to develop strategies for combating initiation of the coagulation cascade. ${ }^{113,130 \text {, }}$ 190,197

\section{Cellular Edema in TBI}

Results of recent studies of TBI have indicated that the predominant type of edema in these injuries is cellular. ${ }^{66}$ These results have been confirmed by other investigators. ${ }^{176}$ It has been documented that ionic dysfunction occurs with TBI and that extracellular $\mathrm{K}^{+}$is transiently increased as a result of the depolarization synchronous with mechanical insult. ${ }^{75,121}$ This loss of ionic homeostasis should be accompanied by a concomitant movement of sodium. Seminal studies by Betz ${ }^{19}$ and Gotoh et al. ${ }^{51}$ measured unidirectional movement of sodium into brain following an ischemic injury, and work by Aldrich et al. ${ }^{4}$ has demonstrated a clear relationship between tissue water content and sodium accumulation in spinal cord injury. Traumatic brain injury is thought to trigger a cascade of events, including mechanical deformation, neurotransmitter release,${ }^{75}$ mitochondrial dysfunction,,${ }^{10,28,132,192}$ and membrane depolarization, ${ }^{75}$ that can lead to alterations in normal ionic gradients. ${ }^{121}$ Excitatory amino acids released via mechanical deformation and membrane depolarization can activate ligand-gated ion channels, which allow ions to move down their electrochemical gradients. In addition, membrane depolarization resulting from ionic flux and trauma may trigger voltage-sensitive ion channels, providing further routes for ionic movement. ${ }^{75}$ These ionic disturbances are identified by an increase in extracellular $\mathrm{K}^{+}$with a concomitant decrease in extracellular $\mathrm{Na}^{+}, \mathrm{Ca}_{2}$, 
and $\mathrm{Cl}^{-}$. Restoration of ionic homeostasis can either occur via energy-dependent co- and countertransport processes such as the $\mathrm{Na}^{+}-\mathrm{K}^{+}$adenosine triphosphatase, the $\mathrm{Na}^{+} /$ $\mathrm{K}^{+} / 2 \mathrm{Cl}^{-}$cotransporter, the $\mathrm{Na}^{+}-\mathrm{H}^{+}$transporter, and the $\mathrm{Na}^{+}-$ $\mathrm{Ca}^{2+}$ exchanger or via simple washout into the vascular or CSF compartment. ${ }^{9,19,116}$ It is reasonable to suspect that the net balance of ionic movement that accompanies brain injury results in the movement of cations out of the extracellular space into cells. The movement of $\mathrm{Na}^{+}$and $\mathrm{Ca}^{-}$is passively followed by $\mathrm{Cl}^{-}$to maintain electroneutrality and is followed isosmotically by water. If sustained, these ionic disturbances result in cellular swelling and cytotoxic edema, which has have shown to be the primary contributor to raised ICP.

\section{Effect of Hypothermia on Cellular Edema}

Mild hypothermia on the order of $32^{\circ} \mathrm{C}$ has been shown to be neuroprotective. The question has been posed if part of this neuroprotection was due to the amelioration of cellular edema. ${ }^{115}$ It was observed that hypothermia itself was causing significant swelling of glial cells in a dose-dependent manner. In that study the authors reported that inhibition of the $\mathrm{Na}^{+} / \mathrm{H}^{(+)}$-antiporter with $50 \mu \mathrm{M} 5 \mathrm{~N}$-ethyl-nisopropyl-amiloride significantly reduced the hypothermia -induced cell swelling, indicating activation of the $\mathrm{Na}^{+} / \mathrm{H}^{(+)}$antiporter. However, mild or moderate hypothermia failed to prevent cell swelling from other toxins (lactic acid, arachidonic acid, or glutamate), mediating the development of cytotoxic brain edema. As a result, it was considered that cerebral protection by hypothermia in vivo is most likely not attributable to an inhibition of cytotoxic brain edema.

\section{Effect of Steroids on Brain Edema}

Despite frequently encouraging experimental results concerning the effectiveness of steroids, particularly in the late $1960 \mathrm{~s}$, clinical trials of glucocorticoids in ischemic stroke, intracerebral hemorrhage, aneurysmal subarachnoid hemorrhage, and TBI have not shown a definite therapeutic effect. ${ }^{9}$ The evidence supporting glucocorticoid therapy for spinal cord injury is controversial; however, methylprednisolone continues to be widely used in this setting. $25-27,46,89,109,153,159,160,162,171,180$ In contrast, in clinical trials for head injury and stroke, corticosteriods have not been shown to be effective in treating cellular edema. ${ }^{139}$

\section{Aquaporins and Their Pivotal Role in Edema}

The recent discovery of AQPs ${ }^{178}$ was acclaimed enthusiastically, given that they may provide a mechanism for massive water movement across the cell membrane. Water permeability was considered to be a special case, because several criteria have been developed to distinguish between transport through pores or diffusion through the lipid bilayer. The identification of the AQP family, a water-conducting protein-based channel consisting of 11 subtypes ubiquitously distributed in tissues and organisms, was a landmark discovery. Despite a common molecular structure, mammalian AQPs have been subdivided into three functional groups according to permeability characteristics. ${ }^{183}$ The AQPs, including AQP0, AQP1, AQP2, AQP4, AQP5, AQP6, are permeable to water. The aquaglyceroporins, including AQP3, AQP7, and AQP8, are permeable to water, glycerol, and urea. The neutral solute channels, including AQP9, are permeable to water, glycerol, urea, purines, pyrimidines, and monocarboxylates. The AQP10, like AQP9, is permeable to water and neutral solutes but is not permeable to urea and glycerol. ${ }^{58}$ The AQPs are ubiquitously distributed in mammalian tissue. To date, the following six AQP subtypes have been described in rodent brain: AQP1, AQP3, AQP4, AQP5, AQP8, and AQP9..$^{12,42,120,181,193}$ Of the six AQP subtypes described in rodent brain, much of the data come from AQP4, one of the first subtypes described in the central nervous system. Aquaporin-4 is expressed in the astroglial endfeet membranes adjacent to blood vessels. ${ }^{119}$ It was observed around all vessels of any size in white and gray matter and in all brain structures currently being studied: forebrain, diencephalons, midbrain, and brainstem..$^{12,181}$ Nicchia et al. ${ }^{118}$ reported that AQP4 was responsible for the fast water transport of cultured astroglial cells and might be a primary factor in ischemia-induced cerebral edema. Moreover, it was observed that mice lacking AQP4 were partially protected from brain edema in water intoxication and ischemic models of brain injury. ${ }^{183}$ In a seminal article, Manley et al. ${ }^{103}$ further showed in AQP4-deficient mice a $35 \%$ decrease of cerebral edema following middle cerebral artery occlusion, as measured by the percentage of hemispheric enlargement. Alterations in the expression of AQP4 in cultured rat astrocytes during hypoxia and reoxygenation were also noted. ${ }^{193}$

Investigators have also reported that an increase of water content in the brain after intraperitoneal injection of distilled water and 8-deamino-arginine vasopressin was greatly delayed in dystrophin-null transgenic mice. ${ }^{178}$ It was also noted in this work that the dystrophin-associated proteins are essential for proper localization of AQP4 protein in brain. These results indicated that AQP4 may play a key role in modulating brain water transport and raised the possibility that AQP4 inhibition could provide a new therapeutic option for reducing brain edema in a wide variety of cerebral disorders. Nevertheless, electron crystallographic analysis of the 3D structure of AQP1 revealed an hourglass-shaped channel with 8 - $\AA$ apertures at both ends and a central constriction ( $3 \AA$ in diameter). ${ }^{116}$ With this configuration, only water molecules in a chain, not solutes, pass successively through the narrow channel. Aquaporins are thus a simple water channel whose upregulation increases the water filtration coefficient of the membrane and allows the passage of water in either direction along the osmotic gradient secondarily to the regulatory or recovery processes. The specific anatomical and cellular localization of the AQP4 water channel, localized on the astrocytic endfoot, has been implicated in playing a major role in water balance. ${ }^{181}$ The finding by Manley et al. ${ }^{103}$ that AQP4 deletion in knockout mice reduces brain edema after acute water intoxication and ischemic stroke implicates new avenues for treatment, particularly if pharmacological modulation of AQP4 is possible. It has been demonstrated in the laboratory that AQP4 can be modulated pharmacologically, $, 86,87$ but more work is needed before translating these results to the patient. 


\section{Regulation of AQP4 Following Injury}

There is some evidence, however inconsistent, regarding regulation of AQP4 after brain injury. In different models inducing neuronal degeneration, AQP4 mRNA was upregulated following BBB disruption. ${ }^{85}$ In a combined head injury model, AQP4 immunostaining was negative and the AQP4 mRNA downregulated in areas with impaired $\mathrm{BBB} .{ }^{78}$ Following cortical impact injury, hemispheric ipsilateral AQP4 was progressively downregulated within the first 48 hours. ${ }^{77}$ Similar results were found following ischemia and hypoxia, ${ }^{193}$ all known to produce a predominantly cytotoxic edema.

\section{Clearance of Vasogenic Edema}

The processes involved in the resolution of vasogenic edema are better understood than those of cellular edema. Fluid moves through the interstitium via both bulk flow and diffusion processes. ${ }^{122,124}$ In vasogenic edema clearance, three possible mechanisms have been considered to be responsible for clearance of extracellular water: 1) migration of extracellular water to the CSF by bulk flow in the presence of pressure gradients; ${ }^{85,143,144}$ 2) glial uptake of the protein components of edema fluid; ;5,188 and 3) reverse vesicular transport from the blood via transendothelial passage. ${ }^{186}$ Authors of studies have shown that the primary route for clearance of a proteinaceous fluid is the CSF pathway. ${ }^{52,124}$ These findings support earlier results by Reulen and colleages, ${ }^{144}$ who demonstrated movement of edema fluid toward the ventricle. In other studies ${ }^{123,124}$ it was noted that during the infusion of fluid into the parenchyma when the edema is pressure driven, the fluid traveled to the cortex by three paths: the extracellular space of the neuropil, the expanded pericapillary space around microvessels, and the expanded perivascular space. The possibility that materials are eliminated by drainage along perivascular channels into the CSF in the subarachnoid space has been reported ${ }^{33}$ Findings of our studies would also suggest that the perivascular spaces of venules and veins are the primary pathway for the efflux of solutes from the brain parenchyma to the CSF space. ${ }^{122-124} \mathrm{~A}$ striking observation in these infusion studies was that neither astrocytes nor neurons were observed to take part in the clearance process, which is in contrast to reports that cellular uptake of protein was the major mechanism for clearance of vasogenic edema. ${ }^{85}$

\section{The Role of AQPs in Edema Clearance}

Papadopoulos et al. ${ }^{128}$ demonstrated in mice killed immediately after 60 minutes of continuous intracerebral infusion that AQP4-null mice developed higher ICP and brain water content compared with wild-type controls. Aquaporin-null mice have reduced brain swelling and improved neurological outcome in models of cellular edema including water intoxication, focal cerebral ischemia, and bacterial meningitis. ${ }^{102,183}$ However, if studied only during the infusion process, the processes of resolution may be misleading as clearance of extracellular edema takes considerable time. ${ }^{122,124}$ Interestingly, AQP9 was upregulated in astrocytes surrounding ischemic lesions, suggesting that AQP9 may play a role in the regulation of postischemic edema. ${ }^{11}$ The role of the AQPs in the clearance process of edema remains to be clarified. In a model of intraparenchymal injection of lipopolysaccharide, it was observed that the first signs of barrier disruption coincided with a strong induction of AQP4 mRNA in perivascular glial cells. Restoration of the barrier was associated with high induction of AQP4 mRNA in parenchymal reactive astrocytes and perivascular glial processes, suggesting that high levels of AQP4 mRNA may be beneficial under these circumstances. ${ }^{170}$

\section{Imaging Techniques Used in Identifying the Type of Edema}

It is possible with the aid of MR imaging techniques to measure the diffusion of water in brain tissue. This is usually expressed as the ADC. A reduction in ADC is interpreted as a decrease in diffusion, whereas an increase in $\mathrm{ADC}$ is associated with an increase in diffusion. In cellular edema, the water is more closely bound and thus it would be expected to result in a decreased ADC. To test this, cytotoxic edema secondary to acute hyponatremia was induced with intraperitoneal injections of $2.5 \%$ dextrose in water and a subcutaneous injection of arginine vasopressin. ${ }^{156}$ It was observed that the ADC was significantly reduced, and plots of ADC compared with total brain water showed a statistically significant inverse linear relationship between ADC and increasing brain water, indicating that ADC may be a sensitive indicator of cytotoxic brain edema and may enable quantitative evaluation of edema using diffusion-weighted imaging. In a photochemical model of cerebral infarction, ADC was measured and was found to be elevated in nonischemic tissue but was diminished in areas with histological evidence of ischemic damage or necrosis. ${ }^{156}$ Similarly, reduced ADCs were found in the rodent middle cerebral artery model of ischemia, and ADCs were positive when fluid was infused into the parenchyma simulating an extracellular edema. ${ }^{66}$ In other experimental studies, the temporal change of water following closed head injury was followed acutely and over 14 days using MR imaging ADC methods. ${ }^{17}$ In these studies, ADC was positive, signifying a vasogenic edema during the first 60 minutes postinjury. However, after this rise, the ADC steadily decreased and was minimal by 7 days postinjury. This study provided supportive evidence that cellular edema played a major role in traumatic brain swelling. ${ }^{16}$ Other studies in which the authors used diffusion tensor in models producing vasogenic and cytoxic edema were correlated with histological findings, and diffusion tensor was found to be altered based on the edema subtype. ${ }^{93-95}$

\section{Summary and Recommendations}

Considerable effort has been expended in understanding the pathophysiology of brain swelling, and it is now clearer that increased brain tissue water and not vascular engorgement plays the most important role in the swelling process leading to raised ICP, reduced $\mathrm{CBF}$, and potential herniation. We now appreciate that the abatement of the edematous process will depend on the type of edema that is contributing to tissue swelling. Extracellular or vaso- 
genic edema production is driven by barrier dynamics following injury. Treatments such as hypothermia, which will suppress prolonged secondary opening of the barrier, may prove to be effective therapies. The depth of hypothermia, its duration, and ideal rates of rewarming have yet to be established. $1,3,32,37,43,65,69-71,82,83,101,104,110,134-$ $137,157,158,163$,

166,168,169,172,173,184,189,196,198 Decompressive craniectomy, which allows the brain to expand as it continues to swell, may also be effective in trauma and continues to be under careful study in the clinical setting. ${ }^{23,34,149}$ Perhaps the most exciting new findings that speak to both the control of production and resolution of edema in both trauma and ischemia are the recent studies by Manley and colleagues ${ }^{103}$ and others who have focused on AQP science..$^{5-8,12,39,86 \text {, }}$ 87,102,117,118,127-129,177,183,193 These water channels offer hope for modulating and abating the devastating effects of fulminating brain edema.

\section{References}

1. Adelson PD, Ragheb J, Kanev P, Brockmeyer D, Beers SR, Brown SD, et al: Phase II clinical trial of moderate hypothermia after severe traumatic brain injury in children. Neurosurgery 56:740-754, 2005

2. Ahn KJ, Lee JW, Hahn ST, Yang DW, Kim PS, Kim HJ, et al: Diffusion-weighted MRI and ADC mapping in FK506 neurotoxicity. Br J Radiol 76:916-919, 2003

3. Alam HB, Rhee P, Honma K, Chen H, Ayuste EC, Lin T, et al: Does the rate of rewarming from profound hypothermic arrest influence the outcome in a swine model of lethal hemorrhage? J Trauma 60:134-146, 2006

4. Aldrich EF, Eisenberg HM, Saydjari C, Luerssen TG, Foulkes MA, Jane JA, et al: Diffuse brain swelling in severely headinjured children. A report from the NIH Traumatic Coma Data Bank. J Neurosurg 76:450-454, 1992

5. Amiry-Moghaddam M, Frydenlund DS, Ottersen OP: Anchoring of aquaporin-4 in brain: molecular mechanisms and implications for the physiology and pathophysiology of water transport. Neuroscience 129:999-1010, 2004

6. Amiry-Moghaddam M, Otsuka T, Hurn PD, Traystman RJ, Haug FM, Froehner SC, et al: An alpha-syntrophin-dependent pool of AQP4 in astroglial end-feet confers bidirectional water flow between blood and brain. Proc Natl Acad Sci U S A 100: 2106-2111, 2003

7. Amiry-Moghaddam M, Williamson A, Palomba M, Eid T, de Lanerolle NC, Nagelhus EA, et al: Delayed K+ clearance associated with aquaporin-4 mislocalization: phenotypic defects in brains of alpha-syntrophin-null mice. Proc Natl Acad Sci U S A 100:13615-13620, 2003

8. Amorini AM, Dunbar JG, Marmarou A: Modulation of aquaporin-4 water transport in a model of TBI. Acta Neurochir Suppl 86:261-263, 2003

9. Andersen BJ, Marmarou A: Post-traumatic selective stimulation of glycolysis. Brain Res 585:184-189, 1992

10. Anonymous: Molecular mechanism of brain injury and oedema. Acta Neurochir Suppl 76:27-28, 2000

11. Badaut J, Hirt L, Granziera C, Bogousslavsky J, Magistretti PJ, Regli L: Astrocyte-specific expression of aquaporin-9 in mouse brain is increased after transient focal cerebral ischemia. J Cereb Blood Flow Metab 21:477-482, 2001

12. Badaut J, Lasbennes F, Magistretti PJ, Regli L: Aquaporins in brain: distribution, physiology, and pathophysiology. J Cereb Blood Flow Metab 22:367-378, 2002

13. Baethmann A, Oettinger W, Rothenfusser W, Kempski O, Unterberg A, Geiger R: Brain edema factors: current state with particular reference to plasma constituents and glutamate. Adv Neurol 28:171-195, 1980
14. Baethmann A, Schurer L, Unterberg A, Wahl W, Staub F, Kempski O: [Mediator substances of brain edema in cerebral ischemia.] Arzneimittelforschung 41:310-315, 1991 (Ger)

15. Barzo P, Marmarou A, Fatouros P, Corwin F, Dunbar J: Magnetic resonance imaging-monitored acute blood-brain barrier changes in experimental traumatic brain injury. $\mathbf{J}$ Neurosurg 85:1113-1121, 1996

16. Barzo P, Marmarou A, Fatouros P, Hayasaki K, Corwin F: Biphasic pathophysiological response of vasogenic and cellular edema in traumatic brain swelling. Acta Neurochir Suppl 70: 119-122, 1997

17. Barzo P, Marmarou A, Fatouros P, Hayasaki K, Corwin F: Contribution of vasogenic and cellular edema to traumatic brain swelling measured by diffusion-weighted imaging. J Neurosurg 87:900-907, 1997

18. Bereczki D, Liu M, Prado GF, Fekete I: Cochrane report: a systematic review of mannitol therapy for acute ischemic stroke and cerebral parenchymal hemorrhage. Stroke 31:2719-2722, 2000

19. Betz AL: Transport of ions across the blood-brain barrier. Fed Proc 45:2050-2054, 1986

20. Betz AL, Ennis SR, Schielke GP: Blood-brain barrier sodium transport limits development of brain edema during partial ischemia in gerbils. Stroke 20:1253-1259, 1989

21. Betz AL, Ennis SR, Schielke GP, Hoff JT: Blood-to-brain sodium transport in ischemic brain edema. Adv Neurol 52:73-80, 1990

22. Betz AL, Keep RF, Beer ME, Ren XD: Blood-brain barrier permeability and brain concentration of sodium, potassium, and chloride during focal ischemia. J Cereb Blood Flow Metab 14:29-37, 1994

23. Bostrom S, Bobinski L, Zsigmond P, Theodorsson A: Improved brain protection at decompressive craniectomy - a new method using Palacos R-40 (methylmethacrylate). Acta Neurochir (Wien) 147:279-281, 2005

24. Boulard G, Marguinaud E, Sesay M: [Osmotic cerebral oedema: the role of plasma osmolarity and blood brain barrier.] Ann Fr Anesth Reanim 22:215-219, 2003 (Fr)

25. Bracken MB: Methylprednisolone and spinal cord injury. J Neurosurg 96:140-142, 2002

26. Bracken MB: Steroids for acute spinal cord injury. Cochrane Database Syst Rev: CD001046, 2002

27. Bracken MB, Holford TR: Neurological and functional status 1 year after acute spinal cord injury: estimates of functional recovery in National Acute Spinal Cord Injury Study II from results modeled in National Acute Spinal Cord Injury Study III. J Neurosurg 96 (3 Suppl):259-266, 2002

28. Buki A, Okonkwo DO, Wang KK, Povlishock JT: Cytochrome $\mathrm{c}$ release and caspase activation in traumatic axonal injury. $\mathbf{J}$ Neurosci 20:2825-2834, 2000

29. Chen H, Sun D: The role of Na-K-Cl co-transporter in cerebral ischemia. Neurol Res 27:280-286, 2005

30. Chen M, Simard JM: Cell swelling and a nonselective cation channel regulated by internal $\mathrm{Ca} 2+$ and ATP in native reactive astrocytes from adult rat brain. J Neurosci 21:6512-6521, 2001

31. Chesnut RM: Medical management of severe head injury: present and future. New Horiz 3:581-593, 1995

32. Clifton GL, Miller ER, Choi SC, Levin HS, McCauley S, Smith KR Jr, et al: Hypothermia on admission in patients with severe brain injury. J Neurotrauma 19:293-301, 2002

33. Cserr HF, Cooper DN, Milhorat TH: Flow of cerebral interstitial fluid as indicated by the removal of extracellular markers from rat caudate nucleus. Exp Eye Res 25 Suppl:461-473, 1977

34. Csokay A, Egyud L, Nagy L, Pataki G: Vascular tunnel creation to improve the efficacy of decompressive craniotomy in posttraumatic cerebral edema and ischemic stroke. Surg Neurol 57:126-129, 2002 
35. Derugin N, Wendland M, Muramatsu K, Roberts TP, Gregory G, Ferriero DM, et al: Evolution of brain injury after transient middle cerebral artery occlusion in neonatal rats. Stroke 31: 1752-1761, 2000

36. Di X, Alves OL, Bullock R: Cytotoxic edema is independent of NMDA ion channel activation following middle cerebral artery occlusion (MCAO). An in vivo autoradiographic and MRI study. Neurol Res 25:329-334, 2003

37. Diao C, Zhu L, Wang H: Cooling and rewarming for brain ischemia or injury: theoretical analysis. Ann Biomed Eng 31: 346-353, 2003

38. Dronne MA, Boissel JP, Grenier E: A mathematical model of ion movements in grey matter during a stroke. J Theor Biol 240:599-615, 2006

39. Eid T, Lee TS, Thomas MJ, Amiry-Moghaddam M, Bjornsen LP, Spencer DD, et al: Loss of perivascular aquaporin 4 may underlie deficient water and $\mathrm{K}+$ homeostasis in the human epileptogenic hippocampus. Proc Natl Acad Sci U S A 102: 1193-1198, 2005

40. Eisenberg HM, Gary HE Jr, Aldrich EF, Saydjari C, Turner B, Foulkes MA, et al: Initial CT findings in 753 patients with severe head injury. A report from the NIH Traumatic Coma Data Bank. J Neurosurg 73:688-698, 1990

41. Ejima Y, Nakamura Y, Michimata M, Hatano R, Kazama I, Sanada S, et al: Transient body fluid accumulation and enhanced NKCC2 expression in gerbils with brain infarction. Nephron Physiol 103:25-32, 2006

42. Elkjaer M, Vajda Z, Nejsum LN, Kwon T, Jensen UB, AmiryMoghaddam M, et al: Immunolocalization of AQP9 in liver, epididymis, testis, spleen, and brain. Biochem Biophys Res Commun 276: 1118-1128, 2000

43. Farstad M, Andersen KS, Koller ME, Grong K, Segadal L, Husby P: Rewarming from accidental hypothermia by extracorporeal circulation. A retrospective study. Eur J Cardiothorac Surg 20:58-64, 2001

44. Feldmann H, Klages G, Gartner F, Scharfenberg J: The prognostic value of intracranial pressure monitoring after severe head injuries. Acta Neurochir Suppl (Wien) 28:74-77, 1979

45. Fotheringham AP, Davies CA, Davies I: Oedema and glial cell involvement in the aged mouse brain after permanent focal ischaemia. Neuropathol Appl Neurobiol 26:412-423, 2000

46. Frampton AE, Eynon CA: High dose methylprednisolone in the immediate management of acute, blunt spinal cord injury: what is the current practice in emergency departments, spinal units, and neurosurgical units in the UK? Emerg Med J 23:550-553, 2006

47. Furukawa T, Hoshino S, Kobayashi S, Asakura T, Takahashi M, Atsumi T, et al: The glutamate AMPA receptor antagonist, YM872, attenuates cortical tissue loss, regional cerebral edema, and neurological motor deficits after experimental brain injury in rats. J Neurotrauma 20:269-278, 2003

48. Gasche Y, Copin JC: [Blood-brain barrier pathophysiology and ischaemic brain oedema.] Ann Fr Anesth Reanim 22: 312-319, 2003 (Fr)

49. Gomes JA, Stevens RD, Lewin JJ III, Mirski MA, Bhardwaj A: Glucocorticoid therapy in neurologic critical care. Crit Care Med 33:1214-1224, 2005

50. Gordon CR, Merchant RS, Marmarou A, Rice CD, Marsh JT, Young HF: Effect of murine recombinant interleukin-1 on brain oedema in the rat. Acta Neurochir Suppl (Wien) 51:268-270, 1990

51. Gotoh O, Asano T, Koide T, Takakura K: Ischemic brain edema following occlusion of the middle cerebral artery in the rat. I: the time courses of the brain water, sodium and potassium contents and blood-brain barrier permeability to $125 \mathrm{I}$-albumin. Stroke 16:101-109, 1985

52. Groger U, Marmarou A: Importance of protein content in the edema fluid for the resolution of brain edema. Adv Neurol 52: 215-218, 1990
53. Gunn AJ, Battin M, Gluckman PD, Gunn TR, Bennet L: Therapeutic hypothermia: from lab to NICU. J Perinat Med 33:340-346, 2005

54. Gunn AJ, Bennet L, Gunning MI, Gluckman PD, Gunn TR: Cerebral hypothermia is not neuroprotective when started after postischemic seizures in fetal sheep. Pediatr Res 46:274-280, 1999

55. Gunn AJ, Thoresen M: Hypothermic neuroprotection. Neuro Rx 3:154-169, 2006

56. Hahn JF: Cerebral edema and neurointensive care. Pediatr Clin North Am 27:587-592, 1980

57. Hakamata Y, Ito U, Kuroiwa T, Hanyu S, Ohashi N, Nakano I: Combined therapy utilizing a novel $\mathrm{Na}+\mathrm{H}+$ exchange inhibitor (SM-20220) and THAM for ischemic brain edema. Acta Neurochir Suppl 76:165-169, 2000

58. Hatakeyama S, Yoshida Y, Tani T, Koyama Y, Nihei K, Ohshiro $\mathrm{K}$, et al: Cloning of a new aquaporin (AQP10) abundantly expressed in duodenum and jejunum. Biochem Biophys Res Commun 287:814-819, 2001

59. Heinemann U: Excitatory amino acids and epilepsy-induced changes in extracellular space size. Adv Exp Med Biol 203: 449-460, 1986

60. Heiss WD: [Therapy of cerebral ischemia.] Z Kardiol 76 (4 Suppl):87-98, 1987 (Ger)

61. Heitsch H: Bradykinin B2 receptor as a potential therapeutic target. Drug News Perspect 13:213-225, 2000

62. Hoehn-Berlage M, Norris DG, Kohno K, Mies G, Leibfritz D, Hossmann KA: Evolution of regional changes in apparent diffusion coefficient during focal ischemia of rat brain: the relationship of quantitative diffusion NMR imaging to reduction in cerebral blood flow and metabolic disturbances. J Cereb Blood Flow Metab 15:1002-1011, 1995

63. Hossmann KA: Non-invasive imaging methods for the characterization of the pathophysiology of brain ischemia. Acta Neurochir Suppl 86:21-27, 2003

64. Hunter CJ, Bennet L, Power GG, Roelfsema V, Blood AB, Quaedackers JS, et al: Key neuroprotective role for endogenous adenosine A1 receptor activation during asphyxia in the fetal sheep. Stroke 34:2240-2245, 2003

65. Hutchison J, Ward R, Lacroix J, Hebert P, Skippen P, Barnes $M$, et al: Hypothermia pediatric head injury trial: the value of a pretrial clinical evaluation phase. Dev Neurosci 28:291-301, 2006

66. Ito J, Marmarou A, Barzo P, Fatouros P, Corwin F: Characterization of edema by diffusion-weighted imaging in experimental traumatic brain injury. J Neurosurg 84:97-103, 1996

67. Ito U, Ohno K, Nakamura R, Suganuma F, Inaba Y: Brain edema during ischemia and after restoration of blood flow. Measurement of water, sodium, potassium content and plasma protein permeability. Stroke 10:542-547, 1979

68. Ito U, Ohno K, Suganuma Y, Suzuki K, Inaba Y: Effect of steroid on ischemic brain edema. Analysis of cytotoxic and vasogenic edema occurring during ischemia and after restoration of blood flow. Stroke 11:166-172, 1980

69. Jiang JY, Xu W, Li WP, Gao GY, Bao YH, Liang YM, et al: Effect of long-term mild hypothermia or short-term mild hypothermia on outcome of patients with severe traumatic brain injury. J Cereb Blood Flow Metab 26:771-776, 2006

70. Jungwirth B, Mackensen GB, Blobner M, Neff F, Reichart B, Kochs EF, et al: Neurologic outcome after cardiopulmonary bypass with deep hypothermic circulatory arrest in rats: description of a new model. J Thorac Cardiovasc Surg 131: 805-812, 2006

71. Kabon B, Bacher A, Spiss CK: Therapeutic hypothermia. Best Pract Res Clin Anaesthesiol 17:551-568, 2003

72. Kalimo H, Rehncrona S, Soderfeldt B, Olsson Y, Siesjo BK: Brain lactic acidosis and ischemic cell damage: 2. Histopathology. J Cereb Blood Flow Metab 1:313-327, 1981

73. Kang TC, An SJ, Park SK, Hwang IK, Yoon DK, Shin HS, et 
al: Changes in $\mathrm{Na}(+)-\mathrm{K}(+)-\mathrm{Cl}(-)$ cotransporter immunoreactivity in the gerbil hippocampus following transient ischemia. Neurosci Res 44:249-254, 2002

74. Karpiak SE, Wakade CG, Tagliavia A, Mahadik SP: Temporal changes in edema, $\mathrm{Na}+\mathrm{K}+$, and $\mathrm{Ca}++$ in focal cortical stroke: GM1 ganglioside reduces ischemic injury. J Neurosci Res 30: 512-520, 1991

75. Katayama Y, Tsubokawa T, Miyazaki S, Kawamata T, Yoshino A: Oedema fluid formation within contused brain tissue as a cause of medically uncontrollable elevation of intracranial pressure: the role of surgical therapy. Acta Neurochir Suppl (Wien) 51:308-310, 1990

76. Kawamata T, Katayama Y, Maeda T, Mori T, Aoyama N, Kikuchi T, et al: Antioxidant, OPC-14117, attenuates edema formation and behavioral deficits following cortical contusion in rats. Acta Neurochir Suppl 70:191-193, 1997

77. Ke C, Poon WS, Ng HK, Lai FM, Tang NL, Pang JC: Impact of experimental acute hyponatremia on severe traumatic brain injury in rats: influences on injuries, permeability of bloodbrain barrier, ultrastructural features, and aquaporin-4 expression. Exp Neurol 178:194-206, 2002

78. Ke C, Poon WS, Ng HK, Pang JC, Chan Y: Heterogeneous responses of aquaporin-4 in oedema formation in a replicated severe traumatic brain injury model in rats. Neurosci Lett 301:21-24, 2001

79. Kempski O, Otsuka H, Seiwert T, Heimann A: Spreading depression induces permanent cell swelling under penumbra conditions. Acta Neurochir Suppl 76:251-255, 2000

80. Kempski O, von Andrian U, Schurer L, Baethmann A: Intravenous glutamate enhances edema formation after a freezing lesion. Adv Neurol 52:219-223, 1990

81. Kimelberg HK, Barron KD, Bourke RS, Nelson LR, Cragoe EJ: Brain anti-cytoxic edema agents. Prog Clin Biol Res 361: 363-385, 1990

82. Kinoshita K, Utagawa A, Ebihara T, Furukawa M, Sakurai A, Noda A, et al: Rewarming following accidental hypothermia in patients with acute subdural hematoma: case report. Acta Neurochir Suppl 96:44-47, 2006

83. Kirkpatrick AW, Chun R, Brown R, Simons RK: Hypothermia and the trauma patient. Can J Surg 42:333-343, 1999

84. Klatzo I: Presidental address. Neuropathological aspects of brain edema. J Neuropathol Exp Neurol 26:1-14, 1967

85. Klatzo I, Chui E, Fujiwara K, Spatz M: Resolution of vasogenic brain edema. Adv Neurol 28:359-373, 1980

86. Kleindienst A, Fazzina G, Amorini AM, Dunbar JG, Glisson R, Marmarou A: Modulation of AQP4 expression by the protein kinase $\mathrm{C}$ activator, phorbol myristate acetate, decreases ischemia-induced brain edema. Acta Neurochir Suppl 96: 393-397, 2006

87. Kleindienst A, Fazzina G, Dunbar JG, Glisson R, Marmarou A: Protective effect of the V1a receptor antagonist SR49059 on brain edema formation following middle cerebral artery occlusion in the rat. Acta Neurochir Suppl 96:303-306, 2006

88. Kogure K, Hara H, Asano T: [Brain ischemia and brain edema.] Tanpakushitsu Kakusan Koso 35:1254-1271, 1990 (Jpn)

89. Kronvall E, Sayer FT, Nilsson OG: [Methylprednisolone in the treatment of acute spinal cord injury has become more and more questioned.] Lakartidningen 102:1887-1888, 1890, 2005 (Swedish)

90. Kumar V, Naik RS, Hillert M, Klein J: Effects of chloride flux modulators in an in vitro model of brain edema formation. Brain Res 1122:222-229, 2006

91. Kuroiwa T, Cahn R, Juhler M, Goping G, Campbell G, Klatzo I: Role of extracellular proteins in the dynamics of vasogenic brain edema. Acta Neuropathol 66:3-11, 1985

92. Kuroiwa T, Ito U, Hakamata Y, Hanyu S, Mies G, Hermann D: Evolution of energy failure after repeated cerebral ischemia in gerbils. Acta Neurochir Suppl 76:43-46, 2000
93. Kuroiwa T, Nagaoka T, Miyasaka N, Akimoto H, Zhao F, Yamada I, et al: Time course of trace of diffusion tensor [Trace(D)] and histology in brain edema. Acta Neurochir Suppl 76:191-194, 2000

94. Kuroiwa T, Nagaoka T, Ueki M, Yamada I, Miyasaka N, Akimoto H: Different apparent diffusion coefficient: water content correlations of gray and white matter during early ischemia. Stroke 29:859-865, 1998

95. Kuroiwa T, Nagaoka T, Ueki M, Yamada I, Miyasaka N, Akimoto $\mathrm{H}$, et al: Correlations between the apparent diffusion coefficient, water content, and ultrastructure after induction of vasogenic brain edema in cats. J Neurosurg 90:499-503, 1999

96. Lassen NA: Pathophysiology of brain ischemia as it relates to the therapy of acute ischemic stroke. Clin Neuropharmacol 13 (3 Suppl): S1-S8, 1990

97. Le Bars E, Roussel S, Remy C, Loubinoux I, Devoulon P, Meric $\mathrm{P}$, et al: Delayed progression of cytotoxic oedema in focal cerebral ischemia after treatment with a torasemide derivative: a diffusion-weighted magnetic resonance imaging study. Neurosci Lett 213:123-126, 1996

98. Lee KR, Betz AL, Keep RF, Chenevert TL, Kim S, Hoff JT: Intracerebral infusion of thrombin as a cause of brain edema. J Neurosurg 83:1045-1050, 1995

99. Lee KR, Colon GP, Betz AL, Keep RF, Kim S, Hoff JT: Edema from intracerebral hemorrhage: the role of thrombin. J Neurosurg 84:91-96, 1996

100. Levin HS, Eisenberg HM, Gary HE, Marmarou A, Foulkes MA, Jane JA, et al: Intracranial hypertension in relation to memory functioning during the first year after severe head injury. Neurosurgery 28:196-200, 1991

101. Liu WG, Qiu WS, Zhang Y, Wang WM, Lu F, Yang XF: Effects of selective brain cooling in patients with severe traumatic brain injury: a preliminary study. J Int Med Res 34: 58-64, 2006

102. Manley GT, Binder DK, Papadopoulos MC, Verkman AS: New insights into water transport and edema in the central nervous system from phenotype analysis of aquaporin-4 null mice. Neuroscience 129:983-991, 2004

103. Manley GT, Fujimura M, Ma T, Noshita N, Filiz F, Bollen $\mathrm{AW}$, et al: Aquaporin-4 deletion in mice reduces brain edema after acute water intoxication and ischemic stroke. Nat Med 6:159-163, 2000

104. Marion DW: Moderate hypothermia in severe head injuries: the present and the future. Curr Opin Crit Care 8:111-114, 2002

105. Marmarou A, Signoretti S, Fatouros PP, Portella G, Aygok GA, Bullock MR: Predominance of cellular edema in traumatic brain swelling in patients with severe head injuries. J Neurosurg 104:720-730, 2006

106. Marshall LF, Becker DP, Bowers SA, Cayard C, Eisenberg H, Gross CR, et al: The National Traumatic Coma Data Bank. Part 1: Design, purpose, goals, and results. J Neurosurg 59: 276-284, 1983

107. Marshall LF, Bowers SA, Alksne JF, Sadler GR: Development of a multinational traumatic coma data bank. Neurosurgery 7:433-434, 1980

108. Marshall LF, Toole BM, Bowers SA: The National Traumatic Coma Data Bank. Part 2: patients who talk and deteriorate: implications for treatment. J Neurosurg 59:285-288, 1983

109. McCutcheon EP, Selassie AW, Gu JK, Pickelsimer EE: Acute traumatic spinal cord injury, 1993-2000. A population-based assessment of methylprednisolone administration and hospitalization. J Trauma 56:1076-1083, 2004

110. McIntyre LA, Fergusson DA, Hebert PC, Moher D, Hutchison JS: Prolonged therapeutic hypothermia after traumatic brain injury in adults: a systematic review. JAMA 289:2992-2999, 2003

111. Menzies SA, Betz AL, Hoff JT: Contributions of ions and albumin to the formation and resolution of ischemic brain edema. J Neurosurg 78:257-266, 1993 
112. Miller JD, Becker DP, Ward JD, Sullivan HG, Adams WE, Rosner MJ: Significance of intracranial hypertension in severe head injury. J Neurosurg 47:503-516, 1977

113. Morenski JD, Tobias JD, Jimenez DF: Recombinant activated factor VII for cerebral injury-induced coagulopathy in pediatric patients. Report of three cases and review of the literature. J Neurosurg 98:611-616, 2003

114. Mori T, Kawamata T, Katayama Y, Maeda T, Aoyama N, Kikuchi T, et al: Antioxidant, OPC-14117, attenuates edema formation, and subsequent tissue damage following cortical contusion in rats. Acta Neurochir Suppl 71:120-122, 1998

115. Mueller E, Wietzorrek J, Ringel F, Guretzki S, Baethmann A, Plesnila N: Influence of hypothermia on cell volume and cytotoxic swelling of glial cells in vitro. Acta Neurochir Suppl 76:551-555, 2000

116. Murata K, Mitsuoka K, Hirai T, Walz T, Agre P, Heymann JB, et al: Structural determinants of water permeation through aquaporin-1. Nature 407:599-605, 2000

117. Nagelhus EA, Mathiisen TM, Ottersen OP: Aquaporin-4 in the central nervous system: cellular and subcellular distribution and coexpression with KIR4.1. Neuroscience 129:905-913, 2004

118. Nicchia GP, Nico B, Camassa LM, Mola MG, Loh N, Dermietzel R, et al: The role of aquaporin-4 in the blood-brain barrier development and integrity: studies in animal and cell culture models. Neuroscience 129:935-945, 2004

119. Nico B, Frigeri A, Nicchia GP, Corsi P, Ribatti D, Quondamatteo F, et al: Severe alterations of endothelial and glial cells in the blood-brain barrier of dystrophic mdx mice. Glia 42:235-251, 2003

120. Nielsen S, Nagelhus EA, Amiry-Moghaddam M, Bourque C, Agre P, Ottersen OP: Specialized membrane domains for water transport in glial cells: high-resolution immunogold cytochemistry of aquaporin-4 in rat brain. J Neurosci 17: 171-180, 1997

121. Nilsson P, Hillered L, Olsson Y, Sheardown MJ, Hansen AJ: Regional changes in interstitial $\mathrm{K}+$ and $\mathrm{Ca} 2+$ levels following cortical compression contusion trauma in rats. J Cereb Blood Flow Metab 13:183-192, 1993

122. Ohata K, Marmarou A: Clearance of brain edema and macromolecules through the cortical extracellular space. J Neurosurg 77:387-396, 1992

123. Ohata K, Marmarou A, Povlishock JT: Immunocytochemical studies of oedema protein clearance in the rat. Acta Neurochir Suppl (Wien) 51:93-95, 1990

124. Ohata K, Marmarou A, Povlishock JT: An immunocytochemical study of protein clearance in brain infusion edema. Acta Neuropathol 81:162-177, 1990

125. Okiyama K, Smith DH, Gennarelli TA, Simon RP, Leach M, McIntosh TK: The sodium channel blocker and glutamate release inhibitor BW1003C87 and magnesium attenuate regional cerebral edema following experimental brain injury in the rat. J Neurochem 64:802-809, 1995

126. Okuyama K, Kiuchi S, Okamoto M, Narita H, Kudo Y: A novel $\mathrm{Na}+$ and $\mathrm{Ca} 2+$ channel blocker, $\mathrm{T}-477$, prevents brain edema following microsphere-induced permanent occlusion of cerebral arterioles in rats. Jpn J Pharmacol 81:170-175, 1999

127. Papadopoulos MC, Krishna S, Verkman AS: Aquaporin water channels and brain edema. Mt Sinai J Med 69:242-248, 2002

128. Papadopoulos MC, Manley GT, Krishna S, Verkman AS: Aquaporin-4 facilitates reabsorption of excess fluid in vasogenic brain edema. FASEB J 18:1291-1293, 2004

129. Papadopoulos MC, Saadoun S, Binder DK, Manley GT, Krishna S, et al: Molecular mechanisms of brain tumor edema. Neuroscience 129:1011-1020, 2004

130. Park P, Fewel ME, Garton HJ, Thompson BG, Hoff JT: Recombinant activated factor VII for the rapid correction of coagulopathy in nonhemophilic neurosurgical patients. Neurosurgery 53:34-39, 2003
131. Pau A, Viale ES, Turtas S, Viale GL: Cerebral water and electrolytes in experimental ischaemia following omental transposition to the brain. Acta Neurochir (Wien) 54:213-218, 1980

132. Pettus EH, Christman CW, Giebel ML, Povlishock JT: Traumatically induced altered membrane permeability: its relationship to traumatically induced reactive axonal change. J Neurotrauma 11:507-522, 1994

133. Phan LH, Hickey MJ, Niazi ZB, Stewart AG: Nitric oxide synthase inhibitor, nitro-iminoethyl-L-ornithine, reduces ischemia-reperfusion injury in rabbit skeletal muscle. Microsurgery 15:703-707, 1994

134. Pokela M, Heikkinen J, Biancari F, Ronka E, Kaakinen T, Vainionpaa $\mathrm{V}$, et al: Topical head cooling during rewarming after experimental hypothermic circulatory arrest. Ann Thorac Surg 75:1899-1911, 2003

135. Preston E, Webster J: A two-hour window for hypothermic modulation of early events that impact delayed opening of the rat blood-brain barrier after ischemia. Acta Neuropathol 108: 406-412, 2004

136. Qiu WS, Liu WG, Shen H, Wang WM, Hang ZL, Zhang Y, et al: Therapeutic effect of mild hypothermia on severe traumatic head injury. Chin J Traumatol 8:27-32, 2005

137. Qiu WS, Wang WM, Du HY, Liu WG, Shen H, Shen LF, et al: Thrombocytopenia after therapeutic hypothermia in severe traumatic brain injury. Chin J Traumatol 9:238-241, 2006

138. Qizilbash N, Lewington SL, Lopez-Arrieta JM: Corticosteroids for acute ischaemic stroke. Cochrane Database Syst Rev: CD000064, 2002

139. Qizilbash N, Lewington SL, Lopez-Arrieta JM: Corticosteroids for acute ischaemic stroke. Cochrane Database Syst Rev: CD000064, 2000

140. Rabinstein AA: Treatment of cerebral edema. Neurologist 12: 59-73, 2006

141. Rama Rao KV, Chen M, Simard JM, Norenberg MD: Suppression of ammonia-induced astrocyte swelling by cyclosporin A. J Neurosci Res 74:891-897, 2003

142. Reinert M, Khaldi A, Zauner A, Doppenberg E, Choi S, Bullock R: High extracellular potassium and its correlates after severe head injury: relationship to high intracranial pressure. Neurosurg Focus 8(1):E10, 2000

143. Reulen HJ, Graham R, Spatz M, Klatzo I: Role of pressure gradients and bulk flow in dynamics of vasogenic brain edema. J Neurosurg 46:24-35, 1977

144. Reulen HJ, Tsuyumu M, Tack A, Fenske AR, Prioleau GR: Clearance of edema fluid into cerebrospinal fluid. A mechanism for resolution of vasogenic brain edema. J Neurosurg 48:754-764, 1978

145. Ringel F, Chang RC, Staub F, Baethmann A, Plesnila N: Contribution of anion transporters to the acidosis-induced swelling and intracellular acidification of glial cells. J Neurochem 75:125-132, 2000

146. Ritz MF, Schmidt P, Mendelowitsch A: Effects of isoflurane on glutamate and taurine releases, brain swelling and injury during transient ischemia and reperfusion. Int $\mathbf{J}$ Neurosci 116: 191-202, 2006

147. Rosenberg GA: Ischemic brain edema. Prog Cardiovasc Dis 42:209-216, 1999

148. Rudolf U, Zoltan N, Zsuzsa J: Ion and metabolic disturbances after global and focal cerebral ischemia. Acta Biomed Ateneo Parmense 66:75-82, 1995

149. Rutigliano D, Egnor MR, Priebe CJ, McCormack JE, Strong N, Scriven RJ, et al: Decompressive craniectomy in pediatric patients with traumatic brain injury with intractable elevated intracranial pressure. J Pediatr Surg 41:83-87, 2006

150. Saito N, Chang C, Kawai K, Joo F, Nowak TS Jr, Mies G, et al: Role of neuroexcitation in development of blood-brain barrier and oedematous changes following cerebral ischaemia and traumatic brain injury. Acta Neurochir Suppl (Wien) 51:186-188, 1990 
151. Sarabia R, Lobato RD, Rivas JJ, Cordobes F, Rubio J, Cabrera A, et al: Cerebral hemisphere swelling in severe head injury patients. Acta Neurochir Suppl (Wien) 42:40-46, 1988

152. Saul TG, Ducker TB: Effect of intracranial pressure monitoring and aggressive treatment on mortality in severe head injury. J Neurosurg 56:498-503, 1982

153. Sayer FT, Kronvall E, Nilsson OG: Methylprednisolone treatment in acute spinal cord injury: the myth challenged through a structured analysis of published literature. Spine J 6: 335-343, 2006

154. Schilling L, Wahl M: Mediators of cerebral edema. Adv Exp Med Biol 474:123-141, 1999

155. Seta K: [Biochemical changes in brain mitochondria following ischemia and brain swelling.] Nippon Geka Hokan 36:224-241, 1967 (Jpn)

156. Sevick RJ, Kanda F, Mintorovitch J, Arieff AI, Kucharczyk J, Tsuruda JS, et al: Cytotoxic brain edema: assessment with diffusion-weighted MR imaging. Radiology 185:687-690, 1992

157. Shafi NI, Mariscalco MM: Considering the use of induced hypothermia in a pediatric patient with traumatic brain injury: a critical appraisal of two meta-analyses. Pediatr Crit Care Med 7:468-472, 2006

158. Shankaran S, Laptook AR, Ehrenkranz RA, Tyson JE, McDonald SA, Donovan EF, et al: Whole-body hypothermia for neonates with hypoxic-ischemic encephalopathy. N Engl J Med 353:1574-1584, 2005

159. Sharma A, Tiwari R, Badhe P, Sharma G: Comparison of methylprednisolone with dexamethasone in treatment of acute spinal injury in rats. Indian J Exp Biol 42:476-480, 2004

160. Shen NJ, Wang YT, Lin QB, Cai J: Using methylprednisolone to supplement direct current electrical field in promoting spinalcord regeneration. J Reconstr Microsurg 21:251-255, 2005

161. Siesjo BK, Smith ML: The biochemical basis of ischemic brain lesions. Arzneimittelforschung 41:288-292, 1991

162. Sipski ML, Pearse DD: Methylprednisolone and other confounders to spinal cord injury clinical trials. Nat Clin Pract Neurol 2:402-403, 2006

163. Skowronski GA: Therapeutic hypothermia after cardiac arrest-not so fast. Crit Care Resusc 7:322-324, 2005

164. Staub F, Peters J, Kempski O, Schneider GH, Schurer L, Baethmann A: Swelling of glial cells in lactacidosis and by glutamate: significance of $\mathrm{Cl}(-)$-transport. Brain Res 610: 69-74, 1993

165. Suarez JI: [Treatment of acute brain edema.] Rev Neurol 32: 275-281, 2001 (Spn)

166. Suehiro E, Ueda Y, Wei EP, Kontos HA, Povlishock JT: Posttraumatic hypothermia followed by slow rewarming protects the cerebral microcirculation. J Neurotrauma 20:381-390, 2003

167. Takahashi H, Koehler RC, Brusilow SW, Traystman RJ: Glutamine synthetase inhibition prevents cerebral oedema during hyperammonemia. Acta Neurochir Suppl (Wien) 51: 346-347, 1990

168. Tisherman SA: Hypothermia and injury. Curr Opin Crit Care 10:512-519, 2004

169. Tokutomi T, Miyagi T, Morimoto K, Karukaya T, Shigemori M: Effect of hypothermia on serum electrolyte, inflammation, coagulation, and nutritional parameters in patients with severe traumatic brain injury. Neurocrit Care 1:171-182, 2004

170. Tomas-Camardiel M, Venero JL, Herrera AJ, De Pablos RM, Pintor-Toro JA, Machado A, et al: Blood-brain barrier disruption highly induces aquaporin- $4 \mathrm{mRNA}$ and protein in perivascular and parenchymal astrocytes: protective effect by estradiol treatment in ovariectomized animals. J Neurosci Res 80: 235-246, 2005

171. Tsutsumi S, Ueta T, Shiba K, Yamamoto S, Takagishi K: Effects of the Second National Acute Spinal Cord Injury Study of high-dose methylprednisolone therapy on acute cervical spinal cord injury-results in spinal injuries center. Spine 31:2992-2997, 2006
172. Ueda Y, Suehiro E, Wei EP, Kontos HA, Povlishock JT: Uncomplicated rapid posthypothermic rewarming alters cerebrovascular responsiveness. Stroke 35:601-606, 2004

173. Ueda Y, Wei EP, Kontos HA, Suehiro E, Povlishock JT: Effects of delayed, prolonged hypothermia on the pial vascular response after traumatic brain injury in rats. J Neurosurg 99: 899-906, 2003

174. Unterberg A, Baethmann AJ: The kallikrein-kinin system as mediator in vasogenic brain edema. Part 1: cerebral exposure to bradykinin and plasma. J Neurosurg 61:87-96, 1984

175. Unterberg A, Polk T, Ellis E, Marmarou A: Enhancement of infusion-induced brain edema by mediator compounds. Adv Neurol 52:355-358, 1990

176. Unterberg AW, Stover J, Kress B, Kiening KL: Edema and brain trauma. Neuroscience 129:1021-1029, 2004

177. Vajda Z, Nielsen S, Sulyok E, Doczi T: [Aquaporins in cerebral volume regulation and edema formation.] Orv Hetil 142:223-225, 2001 (Hungarian)

178. Vajda Z, Pedersen M, Fuchtbauer EM, Wertz K, StodkildeJorgensen H, Sulyok E, et al: Delayed onset of brain edema and mislocalization of aquaporin-4 in dystrophin-null transgenic mice. Proc Natl Acad Sci U S A 99:13131-13136, 2002

179. van der Worp HB, Kappelle LJ: Complications of acute ischaemic stroke. Cerebrovasc Dis 8:124-132, 1998

180. Vaquero J, Zurita M, Oya S, Aguayo C, Bonilla C: Early administration of methylprednisolone decreases apoptotic cell death after spinal cord injury. Histol Histopathol 21: 1091-1102, 2006

181. Venero JL, Vizuete ML, Machado A, Cano J: Aquaporins in the central nervous system. Prog Neurobiol 63:321-336, 2001

182. Verier A, Jomin M, Lozes G, Lesoin F: [Post-traumatic cerebral edema. Physiopathology and treatment.] Sem Hop 60: 673-677, 1984

183. Verkman AS, Yang B, Song Y, Manley GT, Ma T: Role of water channels in fluid transport studied by phenotype analysis of aquaporin knockout mice. Exp Physiol 85:233S-241S, 2000

184. Vespa PM: Slow rewarming: a cool model of posttraumatic hypothermia. Crit Care Med 29:2224-2225, 2001

185. Vizuete ML, Venero JL, Vargas C, Ilundain AA, Echevarria M, Machado A, et al: Differential upregulation of aquaporin-4 mRNA expression in reactive astrocytes after brain injury: potential role in brain edema. Neurobiol Dis 6:245-258, 1999

186. Vorbrodt AW, Lossinsky AS, Wisniewski HM, Suzuki R, Yamaguchi T, Masaoka $\mathrm{H}$, et al: Ultrastructural observations on the transvascular route of protein removal in vasogenic brain edema. Acta Neuropathol 66:265-273, 1985

187. Wahl M, Schilling L, Unterberg A, Baethmann A: Mediators of vascular and parenchymal mechanisms in secondary brain damage. Acta Neurochir Suppl (Wien) 57:64-72, 1993

188. Wolman M, Klatzo I, Chui E, Wilmes F, Nishimoto K, Fujiwara K, et al: Evaluation of the dye-protein tracers in pathophysiology of the blood-brain barrier. Acta Neuropathol 54:55-61, 1981

189. Wu X, Drabek T, Kochanek PM, Henchir J, Stezoski SW, Stezoski J, et al: Induction of profound hypothermia for emergency preservation and resuscitation allows intact survival after cardiac arrest resulting from prolonged lethal hemorrhage and trauma in dogs. Circulation 113:1974-1982, 2006

190. Xi G, Keep RF, Hoff JT: Mechanisms of brain injury after intracerebral haemorrhage. Lancet Neurol 5:53-63, 2006

191. Xie Y, Dengler K, Zacharias E, Wilffert B, Tegtmeier F: Effects of the sodium channel blocker tetrodotoxin (TTX) on cellular ion homeostasis in rat brain subjected to complete ischemia. Brain Res 652:216-224, 1994

192. Xiong Y, Peterson PL, Muizelaar JP, Lee CP: Amelioration of mitochondrial function by a novel antioxidant U-101033E fol- 
lowing traumatic brain injury in rats. J Neurotrauma 14: 907-917, 1997

193. Yamamoto N, Sobue K, Miyachi T, Inagaki M, Miura Y, Katsuya H, et al: Differential regulation of aquaporin expression in astrocytes by protein kinase C. Brain Res Mol Brain Res 95:110-116, 2001

194. Yan Y, Dempsey RJ, Flemmer A, Forbush B, Sun D: Inhibition of $\mathrm{Na}(+)-\mathrm{K}(+)-\mathrm{Cl}(-)$ cotransporter during focal cerebral ischemia decreases edema and neuronal damage. Brain Res 961:22-31, 2003

195. Yan Y, Dempsey RJ, Sun D: Na+-K+-Cl- cotransporter in rat focal cerebral ischemia. J Cereb Blood Flow Metab 21: 711-721, 2001

196. Zhi D, Zhang S, Lin X: Study on therapeutic mechanism and clinical effect of mild hypothermia in patients with severe head injury. Surg Neurol 59:381-385, 2003

197. Zimmerman RD, Maldjian JA, Brun NC, Horvath B, Skolnick $\mathrm{BE}$ : Radiologic estimation of hematoma volume in intracere- bral hemorrhage trial by CT scan. AJNR Am J Neuroradiol 27:666-670, 2006

198. Zydlewski AW, Hasbargen JA: Hypothermia-induced hypokalemia. Mil Med 163:719-721, 1998

Manuscript submitted February 23, 3007.

Accepted April 5, 2007.

This work was supported in part by National Institutes of Health Grant No. NS12587 (M. Ross Bullock, principal investigator/Anthony Marmarou, project principal investigator) and by National Institutes of Health Grant No. NS19235 (Anthony Marmarou, principal investigator).

Address reprint requests to: Anthony Marmarou, Ph.D., Department of Neurosurgery, Virginia Commonwealth University Medical Center, 1001 East Broad Street, Suite 235, P.O. Box 980508, Richmond, Virginia 23298-0508. email: amarmaro@ vcu.edu. 